\title{
References
}

1. Velychko V. O. Fiziolohichnyy stan orhanizmu tvaryn, biolohichna tsinnist' moloka i yalovychyny ta yikh korektsiya za riznykh ekolohichnykh umov seredovyshcha. Monohrafiya: / V. O. Velychko // L'viv: Kvart, 2007. - 294 s.

2. Pylypiv I. I., Fedoruk R. S. Dzherela zabrudnennya dovkillya okremymy vazhkymy metalamy ta yikh vplyv na zhyttyezdatnist' orhanizmu tvaryn // NTB instytut biolohiyi tvaryn.2000.-Vyp. 2.- S. 26-32.

3. Rivis Y. F., Fedoruk R. S., Velychko V. O. Obminni protsesy v pechintsi zhuynykh tvaryn z riznykh ekolohichnykh zon // Materialy nauk.-prakt. seminaru-simpoziumu. - Kuznetsovs'k L'viv. - 1995.- S. 28-31.

4. Fedoruk R. S., Humenyuk V. V., Kolisnyk H. V. Fizioloho-biokhimichnyy status orhanizmu koriv v umovakh ekolohichnoho zabrudnennya dovkillya // NTB IZBT, — L'viv, 1999, — Vyp. 1(3).-S. 282-285.

5. Mikroelementnyy sklad kormiv i yikh vykorystannya v orhanizmi molodnyaka VRKH v riznykh ekolohichnykh zonakh/ V. O. Velychko, M. V. Luz, I. M. Fostyk ta in. // Materialy nauk.prakt. seminaru-simpoziumu.- Kuznetsovs'k-L'viv. - 1995.- S. 22-25.

Рецензент — Р. С. Федорук, д. вет. н., професор, членкор НААН, Інститут біології тварин НААН.

УДК 619:612.821:612.128:636.2

doi: $10.36359 /$ scivp.2019-20-2.02

\section{ВМІСТ ЛІТІЮ В КРОВІ КОРІВ ІЗ РІЗНИМ ВЕГЕТАТИВНИМ СТАТУСОМ, ЗАЛЕЖНО ВІД ПОРИ РОКУ}

\author{
О. В. Журенко, канд. вет. наук, дочент, \\ B. I. Карповський, д-р вет. наук, професор, \\ О. В. Данчук, д-р вет. наук, дочент
}

Національний університет біоресурсів і природокористування України вул. Героїв Оборони, 15, м. Київ-41, 03041, Україна

Наведено результати досліджень впливу тонусу автономної нервової системи на вміст Літію в крові корів, залежно від пори року. Вміст металу в сироватиі, ціільній крові та клітинах крові корів, залежно від їх вегетативного статусу та пори року, становить, відповідно, 0,42-0,51 мкг/100 мл, 0,34-0,41 мкг/100 мл та 0,17-1,22 мкг/100 мл. Встановлено, що пора року чинить достовірний вплив лише на вміст Літію в сироватиі та цільній крові корів, у яких переважає тонус симпатичного відділу автономної нервової системи. Встановлено залежність вмісту Літію у крові корів від тонусу автономної нервової системи. Переважання впливу на роботу серия парасимпатичного відділу автономної нервової системи, незалежно від пори року, не чинить вплив на вміст Літію в сироватці, ијільій крові та ї̈ клітинах. Переважання впливу на роботу серия симпатичного відділу автономної нервової системи влітку чинить достовірний вплив лише на вміст Літію в клітинах крові $\eta_{\chi}^{2}=0,58(p<0,05)$, тодi, як взимку цей вплив стає сильнішим - $\eta_{\chi}^{2}=0,73(p<0,01)$. Так, 
влітку та взимку вміст даного металу в крові корів-симпатикотоніків був достовірно меншим, відповідно, на $15,7 \%(p<0,05)$ ma 15,9\% $(p<0,015)$ від такого у твариннормотоніків. Вміст Літію в різних фракиіях крові має обернені взаємозв'язки з тонусом автономної нервової системи корів взимку $(r=-0,73-0,84 ; p<0,01-0,001)$, тод $i$, як у теплу пору року вони стають недостовірні.

Ключові слова: КОРОВИ, АВТОНОМНА НЕРВОВА СИСТЕМА, ЛІТІЙ. РЕГРЕСІЙНИЙ АНАЛІЗ.

Вивчення фізіологічних і біохімічних закономірностей життєдіяльності тварин, їх поведінки створює передумови для реалізації генетичного потенціалу організму. Разом 3 тим, будь які зовнішні подразники, що мають місце в кожному тваринницькому господарстві, стають причиною зрушення гомеостазу та виникнення відповідних реакцій як засобу захисту від цих змін. Провідна роль у мобілізації адаптаційних можливостей організму належить нейрогуморальним механізмам, передусім діяльності центральної нервової системи [1]. Одну з провідних ролей у процесі адаптації організму до зміни умов середовища відіграє автономна нервова система (АНС). Симпатична iї частина мобілізує ресурси організму у відповідь на дію стрес-факторів, а парасимпатична - здійснює поточну регуляцію фізіологічних процесів [2]. Саме тому АНС та іiі регуляторні впливи відповідають за всі внутрішні процеси організму, забезпечують відносну динамічну сталість внутрішнього середовища та виконують адаптаційно-трофічну функцію - регуляцію обміну речовин, відповідно до умов навколишнього середовища. Контроль за вегетативними функціями формується ієрархічно під впливом центральної нервової системи, зокрема кори великого мозку.

Симпатичні і парасимпатичні центри АНС знаходяться в стані безперервного збудження, що має назву «тонус». Тонус АНС розглядають з одного боку, як один із проявів гомеостазу, а з іншого, як один з механізмів його регуляції [4]. Переважання тонічного впливу парасимпатичної і симпатичної частин АНС прийнято визначати як ваго- та симпатикотонію. Ваготонія характеризується уповільненим пульсом, схильністю до почервоніння, пітливістю, шлунковими розладами, а симпатикотонія - навпаки [2, 4].

Сьогодні встановлені особливості метаболізму у тварин різного тонусу АНС, однак, повідомлень щодо регуляторного впливу тонусу АНС на мінеральний обмін відсутні.

Отже, проведення комплексних досліджень 3 вивчення вмісту Літію у крові корів різного тонусу АНС $є$ актуальним, оскільки дозволить поглибити існуючі знання про вегетативну регуляцію обміну мікроелементів у організмі тварин.

Мета роботи - встановити вміст Літію в крові корів з різним вегетативним статусом, залежно від пори року.

Матеріали і методи. Досліди проводили на коровах української чорно-рябої породи 23-ї лактації. Тонус АНС корів визначали за допомогою тригеміновагального тесту. Відповідно до отриманих результатів, тварину відносили до нормо-, симпатико- чи ваготоніків. За результатами дослідження тонусу АНС було сформовано 3 дослідні групи (по 5 тварин у кожній): I - корови-нормотоніки, II - ваготоніки, III - симпатикотоніки. Матеріалом для досліджень слугували зразки крові тварин, отримані з яремної вени зранку до годівлі. Відбір крові проводили двічі, улітку і зимою. Цільну кров стабілізували за допомогою гепарину, сироватку крові отримували методом відстоювання, а клітини крові отримували шляхом центрифугування гепаризованої крові, відбирання плазми та триразового промивання клітин у холодному ізотонічному розчині з наступним центрифугуванням [3]. У цільній крові, сироватці та клітинах крові визначали вміст Літію методом атомно-абсорбційної спектрофотометрії в полум'яному режимі [5].

Експериментальні дослідження узгоджуються з основними принципами “Свропейської конвенції з захисту хребетних тварин, що використовуються для експериментальних та 
наукових цілей" (Страсбург, 1986) та декларації "Про гуманне ставлення до тварин" (Гельсінкі, 2000). Одержані цифрові дані опрацьовували статистично за допомогою прикладного програмного комплексу «Microsoft Office Excel 2013». Визначали середньоарифметичну величину (M), iї похибку (m). Ймовірність різниць середніх значень встановлювали за критерієм Стьюдента. Зміни показників вважали достовірними при р<0,05 (в тому числі $\mathrm{p}<0,01$ і $\mathrm{p}<0,001$ ). Крім цього, проводили кореляційний, регресійний, одно- та двофакторний дисперсійний аналіз отриманих результатів.

Результати й обговорення. Вміст Літію в крові корів з різним вегетативним статусом. Проведеними дослідженнями встановлено, що у тварин з різни тонусом АНС вміст Літію в різних фракціях крові не виходив за фізіологічні межі та достовірно різнився (табл. 1). Так, вміст металу в сироватці, цільній крові та клітинах крові корів, залежно від вегетативного статусу корів та пори року, становив відповідно 0,42-0,51 мкг/100 мл, 0,34-0,41 мкг/100 мл та 0,17-1,22 мкг/100 мЛ.

Таблиия 1

Вміст Літію в крові корів різного вегетативного статусу залежно від пори року (мкг/100 мл; M \pm m, n=5)

\begin{tabular}{|c|c|c|c|}
\hline \multirow{2}{*}{ Субстрат } & \multicolumn{3}{|c|}{ Вегетативний статус } \\
\hline & Нормотоніки & Ваготоніки & Симпатикотоніки \\
\hline \multicolumn{4}{|c|}{ Літо } \\
\hline Сироватка & $0,505 \pm 0,015$ & $0,493 \pm 0,009$ & $0,465 \pm 0,017$ \\
\hline Цільна кров & $0,410 \pm 0,012$ & $0,398 \pm 0,010$ & $0,370 \pm 0,013$ \\
\hline Клітини крові & $0,223 \pm 0,008$ & $0,218 \pm 0,011$ & $0,188 \pm 0,009 *$ \\
\hline $\mathrm{Li}_{\text {клітин }} / \mathrm{Li}_{\text {сироватки }}$ & $0,440 \pm 0,002$ & $0,442 \pm 0,024$ & $0,403 \pm 0,013 *$ \\
\hline \multicolumn{4}{|c|}{ Зима } \\
\hline Сироватка & $0,465 \pm 0,017$ & $0,488 \pm 0,013$ & $0,420 \pm 0,011$ \\
\hline Цільна кров & $0,378 \pm 0,015$ & $0,393 \pm 0,010$ & $0,335 \pm 0,010$ \\
\hline Клітини крові & $0,205 \pm 0,006$ & $0,215 \pm 0,006$ & $0,173 \pm 0,005^{* *}$ \\
\hline $\mathrm{Li}_{\text {клітин }} / \mathrm{Li}_{\text {сироватки }}$ & $0,441 \pm 0,009$ & $0,441 \pm 0,003$ & $0,411 \pm 0,011$ \\
\hline
\end{tabular}

Слід відмітити, що вміст даного металу в крові корів-ваготоніків, незалежно від пори року, достовірно не відрізнявся від такого у корів з нормальним тонусом АНС. Тоді, як влітку, так і взимку в клітинах крові корів- симпатикотоніків вміст Літію був достовірно менше на $15,7 \%(\mathrm{p}<0,05)$ та $15,9 \%(\mathrm{p}<0,015)$ від такого у тварин-нормотоніків. Достовірних відмінностей вмісту цього металу в сироватці та цільній крові корів корів-симпатикотоніків порівняно до тварин з нормальним тонусом АНС не встановлено.

Відношення вмісту Літію в клітинах крові до такого ж у сироватці крові корів ( $\mathrm{Li}_{\text {клітин }} / \mathrm{Li}_{\text {сироватки }}$ ), залежно від пори року, становить $0,40-0,44$ ум. од. Слід відмітити, що значення даного показника лише влітку в корів симпатикотоніків достовірно відрізняється від такого у тварин-нормотоніків (менше на $8,5 \%$; $<<0,05$ ).

Пора року чинить достовірний вплив лише на вміст Літію в сироватці та цільній крові, у яких переважає тонус симпатичного відділу АНС. Так, у холодну пору року вміст Літію в цільній крові та сироватці крові цих тварин менше на 9,5-9,7 \% (p < 0,015) від таких показників у теплу пору року.

Встановлено взаємозв’язок тонусу АНС у корів з вмістом Літію в крові залежно від пори року.

Влітку тонус автономної нервової системи у корів достовірно не пов'язаний з вмістом Літію в цільній крові $(\mathrm{r}=-0,45)$, сироватці $(\mathrm{r}=-0,41)$ та клітинах крові $(\mathrm{r}=-0,54)$, однак взимку встановлено достовірні обернені кореляційні зв'язки вмісту даного металу у різних фракціях крові з тонусом автономної нервової системи ( $\mathrm{r}=-0,73-0,84 ; \mathrm{p}<0,01-0,001)$. Показник трансмембранного потенціалу за Літієм також достовірно пов'язаний з тонусом автономної нервової системи у холодну пору року $(\mathrm{r}=-0,61 ; \mathrm{p}<0,05)$. 
Проведеними дослідженнями встановлено вплив вегетативного статусу корів на вміст Літію в крові корів залежно від пори року (табл. 2).

Вплив вегетативного статусу корів $\left(\eta^{2} \chi\right)$ на вміст Літію в крові, залежно від пори року (ум. од., n=12)

\begin{tabular}{|l|c|c|c|c|}
\hline \multirow{2}{*}{ Субстрати } & \multicolumn{2}{|c|}{ Ваготоніки } & \multicolumn{2}{c|}{ Симпатикотоніки } \\
\cline { 2 - 5 } & Літо & Зима & Літо & Зима \\
\hline Сироватка & 0,08 & 0,16 & 0,34 & 0,45 \\
\hline Цільна кров & 0,10 & 0,10 & 0,47 & 0,48 \\
\hline Клітини крові & 0,02 & 0,18 & $0,58^{*}$ & $0,73^{* *}$ \\
\hline $\mathrm{Li}_{\text {клітин } / \mathrm{Li}}$ сироватки & 0,00 & 0,00 & $0,59^{*}$ & 0,41 \\
\hline
\end{tabular}

Примітка: показники достовірні при: $\mathrm{p}<0,05-* ; \mathrm{p}<0,01-{ }^{* *} ; \mathrm{p}<0,001-* * *$.

Переважання впливу на роботу серця парасимпатичного відділу автономної нервової системи незалежно від пори року не чинить вплив на вміст Літію в сироватці, цільній крові та іiі клітинах $\left(\eta^{2} x=0,02-0,18\right)$.

Переважання впливу на роботу серця симпатичного відділу автономної нервової системи влітку чинить достовірний вплив лише на вміст Літію в клітинах крові $-\eta^{2} \chi=0,58$ ( $\mathrm{p}$ $<0,05)$, тоді, як взимку цей вплив стає сильнішим $-\eta^{2} x=0,73(\mathrm{p}<0,01)$, однак вплив на вміст Літію в сироватці та цільній крові залишається недостовірним $\left(\eta^{2} \chi=0,45-0,48\right)$ як і влітку $\left(\eta^{2} \chi\right.$ $=0,37-0,47)$.

Встановлено вплив тонусу АНС у корів-симпатикотоніків на трансмембранний потенціал за Літієм взимку $-\eta^{2} \chi=0,59(\mathrm{p}<0,05)$, тоді, як влітку даний вплив недостовірний $\left(\eta^{2} \chi=0,00\right)$.

Регресійним аналізом встановлено залежність вмісту Літію у крові корів від тонусу автономної нервової системи (табл. 3).

Таблиия 3

Регресійний аналіз залежності вмісту Літію в крові корів від тонусу АНС (ум. од.; n=12)

\begin{tabular}{|l|c|c|c|c|c|c|c|c|}
\hline \multirow{3}{*}{ Показники } & \multicolumn{9}{|c|}{ Субстрат } \\
\cline { 2 - 9 } & \multicolumn{2}{|c|}{ Сироватка крові } & \multicolumn{2}{|c|}{ Цільна кров } & \multicolumn{2}{c|}{ Клітини крові } & \multicolumn{2}{c|}{$\mathrm{Li}_{\text {кліг./ }} / \mathrm{Li}_{\text {сиров. }}$} \\
\cline { 2 - 9 } & Літо & Зима & Літо & Зима & Літо & Зима & Літо & Зима \\
\hline Коефіціснт регресії & $-0,001$ & $-0,003^{* *}$ & $-0,001$ & $-0,002^{* *}$ & $-0,001$ & $-0,002^{* *}$ & $-0,001$ & $-0,001^{*}$ \\
\hline $\mathrm{R}$-квадрат & 0,17 & $0,57^{* *}$ & 0,21 & $0,54^{* *}$ & 0,29 & $0,71^{* *}$ & 0,20 & $0,37^{*}$ \\
\hline
\end{tabular}

Примітка: показники достовірні при: $\mathrm{p}<0,05-{ }^{*} ; \mathrm{p}<0,01-* * ; \mathrm{p}<0,001-* * *$.

Так, лише взимку при зміні різниці частоти серцевих скорочень за результатами тригеміновагального тесту в корів на одну одиницю, вміст Літію: в сироватці крові змінюється у протилежному напрямку на 0,003 мг/100 мл (р < 0,01); в цільній крові і клітинах крові змінюється у протилежному напрямку на 0,002 мг/100 мл $(\mathrm{p}<0,01)$; а показник відношення даного мікроелемента клітинах крові до сироватки крові корів змінюється у протилежному напрямку на 0,001 ум. од. (p <0,05). При чому, взимку до $57 \%(\mathrm{p}<0,01)$ варіацій даного вмісту цього елемента у сироватці крові, до $54 \%(\mathrm{p}<0,05)$ - у цільній крові та до $71 \%(\mathrm{p}<0,001)$ в клітинах крові можуть бути зумовлені тонусом автономної нервової системи тварин. Слід відмітити, що регресійним аналізом достовірної залежності вмісту Літію у різних фракціях крові корів від вегетативного статусу тварин у теплу пору року не встановлено.

Результати проведеного багатофакторного дисперсійного аналізу впливу тонусу автономної нервової системи та пори року на вміст Літію в крові корів наведено у таблиці 4.

Встановлено достовірну залежність від тонусу автономної нервової системи корів вмісту Літію в сироватці крові $(\mathrm{F}=6,98>\mathrm{FU}=3,55 ; \mathrm{p}<0,001)$, цільній крові $(\mathrm{F}=8,32>\mathrm{FU}=$ $3,55 ; \mathrm{p}<0,01)$ та клітинах крові корів $(\mathrm{F}=13,1>\mathrm{FU}=3,55 ; \mathrm{p}<0,001)$. Пора року достовірно впливає на вміст Літію в сироватці крові $(\mathrm{F}=6,92>\mathrm{FU}=4,41 ; \mathrm{p}<0,05)$ та цільній крові $(\mathrm{F}=$ 
$6,23>\mathrm{FU}=4,41 ; \mathrm{p}<0,05)$. Крім цього, на відміну від пори року, вегетативний статус корів достовірно впливає на показник відношення вмісту літію в клітинах і сироватці крові $-\mathrm{F}=$ $4,85>\mathrm{FU}=3,55 ; \mathrm{p}<0,05$.

За результатами дисперсійного аналізу вмісту Літію в різних фракціях крові корів достовірну взаємодію між тонусу автономної нервової системи та порою року не встановлено.

Таблиця 4

Багатофакторний дисперсійний аналіз впливу тонусу автономної нервової системи на вміст Літію в крові корів

\begin{tabular}{|c|c|c|c|c|c|c|}
\hline Джерело варіації & SS & Df & MS & $\mathrm{F}$ & Р-значення & F критичне \\
\hline \multicolumn{7}{|c|}{ Сироватка крові } \\
\hline Тонус АНС & 0,011 & 2 & 0,005 & 6,98 & 0,006 & 3,55 \\
\hline Пора року & 0,005 & 1 & 0,005 & 6,92 & 0,017 & 4,41 \\
\hline Взаємозв'язок & 0,002 & 2 & 0,001 & 1,22 & 0,319 & 3,55 \\
\hline Внутрішня & 0,014 & 18 & 0,001 & & & \\
\hline Всього & 0,032 & 23 & & & & \\
\hline \multicolumn{7}{|c|}{ Цільна кров } \\
\hline Тонус АНС & 0,009 & 2 & 0,005 & 8,32 & 0,003 & 3,55 \\
\hline Пора року & 0,004 & 1 & 0,004 & 6,23 & 0,023 & 4,41 \\
\hline Взаємозв'язок & 0,001 & 2 & 0,001 & 0,99 & 0,393 & 3,55 \\
\hline Внутрішня & 0,010 & 18 & 0,001 & & & \\
\hline Всього & 0,024 & 23 & & & & \\
\hline \multicolumn{7}{|c|}{ Клітини крові } \\
\hline Тонус АНС & 0,007 & 2 & 0,003 & 13,12 & $<0,001$ & 3,55 \\
\hline Пора року & 0,001 & 1 & 0,001 & 3,27 & 0,087 & 4,41 \\
\hline Взаємозв'язок & 0,0003 & 2 & 0,0001 & 0,52 & 0,605 & 3,55 \\
\hline Внутрішня & 0,005 & 18 & 0,0003 & & & \\
\hline Всього & 0,0121 & 23 & & & & \\
\hline \multicolumn{7}{|c|}{$\mathrm{Li}_{\text {клітин }} / \mathrm{Li}_{\text {сироватки }}$} \\
\hline Тонус АНС & 0,006 & 2 & 0,003 & 4,85 & 0,020609 & 3,55 \\
\hline Пора року & $<0.001$ & 1 & $<0.001$ & 0.07 & 0.801229 & 4.41 \\
\hline Взаємозв'язок & $<0,001$ & 2 & $<0,001$ & 0,07 & 0,928681 & 3,55 \\
\hline Внутрішня & 0,012 & 18 & 0,001 & & & \\
\hline Всього & 0,019 & 23 & & & & \\
\hline
\end{tabular}

Отже, проведені дослідження свідчать про наявність кортико-вегетативних механізмів регуляції обміну Літію в крові корів.

\section{В И С Н О В К И}

1. Вміст Літію в сироватці, цільній крові та клітинах крові корів становить відповідно 0,42-0,51 мкг/100 мл, 0,34-0,41 мкг/100 мл та 0,17-1,22 мкг/100 мл.

2. Пора року чинить достовірний вплив лише на вміст Літію в сироватці та цільній крові корів, у яких переважає тонус симпатичного відділу автономної нервової системи.

3. Вміст Літію в клітинах крові корів-симпатикотоніків, залежно від пори року, достовірно менший на $15,7-15,9 \%$ ( $<<0,05)$ від такого у тварин-нормотоніків.

4. Переважання впливу на роботу серця симпатичного відділу автономної нервової системи влітку чинить достовірний вплив на вміст Літію в клітинах крові $-\eta^{2} \chi=0,58(\mathrm{p}<0,05)$, причому, взимку цей вплив стає сильнішим $-\eta^{2} x=0,73(\mathrm{p}<0,01)$.

5. Вміст Літію в різних фракціях крові має обернені взаємозв'язки з тонусом автономної нервової системи корів взимку $-\mathrm{r}=-0,73-0,84(\mathrm{p}<0,01-0,001)$.

Перспективи досліджень. Перспективи досліджень полягають у розробці сучасних методів та способів корекції вмісту макро- та мікроелементів у крові корів з урахуванням індивідуальних особливостей їх нервової системи. 


\title{
THE CONTENT OF LITHIUM IN THE BLOOD OF COWS WITH DIFFERENT VEGETATIVE STATUS, DEPENDING ON THE TIME OF THE YEAR
}

\author{
O. V. Zhurenko, V. I. Karpovskiy, O. V. Danchuk \\ National University of Life and Environmental Sciences of Ukraine \\ 15, Herois Oborony str., Kyiv-41, 03041, Ukraine
}

\section{S U M M A R Y}

The results of studies of the influence of autonomic nervous system tonus on the content of lithium in the blood of cows depending on the time of year are presented. The content of metal in the serum, whole blood and blood cells of cows, depending on their vegetative status and season were $0.42-0.51 \mu \mathrm{g} / 100 \mathrm{ml}, 0.34-0.41 \mu \mathrm{g} / 100 \mathrm{ml}$ and $0.17-1.22 \mu \mathrm{g} / 100 \mathrm{ml}$ respectively. It is established that the time of year had a significant effect on the content of lithium only in serum and whole blood of cows in which the tonus of the sympathetic division of the autonomic nervous system predominated. The lithium content in the blood of cows and tonus of the autonomic nervous system dependence was confirmed. The predominance of the parasympathetic division of the autonomic nervous system influence on the heart, regardless of the season, does not effect the content of lithium in serum, whole blood and its cells. The predominance of the sympathetic division of the autonomic nervous system influence on the heart in summer had significant effect only on the content of lithium in blood cells $-\eta_{x}^{2}=0,58(p<0,05)$, whereas in winter this influence became stronger $-\eta_{x}^{2}=0,73($ $\mathrm{p}<0.01)$. Thus, in summer and winter, the content of this metal in the blood of sympathicotonic cows was significantly lower by $15.7 \%(\mathrm{p}<0.05)$ and $15.9 \%(\mathrm{p}<0.015)$, respectively, than that in normotonic animals.

Lithium content in different blood fractions had an inverse relationship with the tonus of the autonomic nervous system of cows in winter $(r=-0.73-0.84 ; p<0.01-0.001)$, whereas during the warm season they became insignificant. ANALYSIS.

Keywords: COWS, AUTONOMIC NERVOUS SYSTEM, LITHIUM, REGRESSION

\section{СОДЕРЖАНИЕ ЛИТИЯ В КРОВИ КОРОВ С РАЗНЫМ ВЕГЕТАТИВНЫМ СТАТУСОМ В ЗАВИСИМОСТИ ОТ ВРЕМЕНИ ГОДА}

\author{
Е. В. Журенко, В. И. Карповский, О. В. Данчук \\ Национальный университет биоресурсов и природопользования Украины \\ ул. Героев Обороны, 15, г..Киев-41, 03041, Украина
}

\section{А Н Н О Т А ЦИ Я}

Приведены результаты исследований влияния тонуса вегетативной нервной системы на содержание Лития в крови коров, в зависимости от времени года. Содержание металла в сыворотке, цельной крови и клетках крови коров в зависимости от их вегетативного статуса и времени года составляет соответственно 0,42-0,51 мкг/100 мл, 0,34-0,41 мкг / 100 мл и 0,171,22 мкг/100 мл. Установлено, что время года оказывает достоверное влияние только на содержание Лития в сыворотке и цельной крови коров, в которых преобладает тонус симпатического отдела вегетативной нервной системы. Установлена зависимость содержания Лития в крови коров от тонуса вегетативной нервной системы. Преобладание влияния на работу сердца парасимпатического отдела автономной нервной системы независимо от 
времени года не оказывает влияние на содержание Лития в сыворотке, цельной крови и ее клетках. Преобладание влияния на работу сердца симпатического отдела вегетативной нервной системы летом оказывает достоверное влияние только на содержание Лития в клетках крови - $\eta^{2} x=0,58(\mathrm{p}<0,05)$, тогда как зимой это влияние становится сильнее $-\eta^{2} x=0,73(\mathrm{p}<0,01)$. Так, летом и зимой содержание данного металла в крови коров-симпатикотоников был достоверно меньше соответственно на $15,7 \%(\mathrm{p}<0,05)$ и $15,9 \%(\mathrm{p}<0,015)$ от такового у животных-нормотоников. Содержание Лития в различных фракциях крови имеет обратные взаимосвязи с тонусом вегетативной нервной системы коров зимой $(\mathrm{r}=-0,73-0,84 \mathrm{p}<0,01$ 0,001), тогда, как в теплое время года они становятся недостоверны.

Ключевые слова: КОРОВЫ, АВТОНОМНАЯ НЕРВНАЯ СИСТЕМА, ЛИТИЙ. РЕГРЕССИОННЫЙ АНАЛИЗ.

\section{Л I T Е P A T У P A}

1. Карповський B. I. Типи вищої нервової діяльності великої рогатої худоби та характер адаптаційних реакцій на дію зовнішніх подразників: автореф. дис. ... докт. вет. наук / В. І. Карповський; НУБіП України. - К., 2011. - 42 с.

2. Ноздрачев А. Д. Физиология вегетативной нервной системы / А. Д. Ноздрачев. - Л.: Наука, 1983. - $296 \mathrm{c.}$

3. Влізло В. В. Лабораторні методи досліджень у біології, тваринництві та ветеринарній медицині / В. В. Влізло, Р. С. Федорук, І. Б. Ратич [та ін.] // Львів: СПОЛОМ. -2012. -764 с.

4. Авиьын А. П. Микроэлементози человека: етиология, классификация, органопатология / А. П. Авцын, А. А. Жаворонков, М. А.Риш [и др.] // М.: Медицина. - 1991. - С. 4.

5. Левченко В. I. Ветеринарна клінічна біохімія / В. І. Левченко, В. В. Влізло, I. П. Кондрахін [та ін.] // Біла Церква. - 2002. - С. 177-180.

\section{References}

1. Karpovs'kiy, V. I. (2011). Tipi vishchoï nervovoï diyal'nosti velikoï rogatoï khudobi ta harakter adaptatsiynikh reaktsiy na diyu zovnishnikh podraznikiv: avtoref. dis. ... dokt. vet. nauk / NUBiP Ukraïni. - K., 42. (in Ukrainian).

2. Nozdrachev A. D. (1983). Fiziologiya vegetativnoy nervnoy sistemy. - L.: Nauka, 296. (in Ukrainian).

3. Vlizlo, V. V. (2012). Laboratorni metodi doslidzhennya u biologiï, tvarinnitstvi ta eterinarniy meditsini. Dovidnik / Za red. V. V. Vlizla. - L'viv: Spolom, 760. (in Ukrainian)

4. Avcyn, A. P. Avcyn, A.P. Zhavoronkov, A. A. Rish, M.A Strochkova L.S. et.al (1991). Mikrojelementozi cheloveka: etiologija, klassifikacija, organopatologija [Mikroelementozi rights: etiology, classification, organopathology] M.: Medicina. 4 (in Russian).

5. Levchenko, V. I. Vlizlo, V.V. Kondrahin, I. P. (2002). Veterinarna klinichna biohimija. [Veterinary Clinical Biochemistry] Bila Cerkva. 177-180 (in Ukrainian).

Рецензент - М. О. Малюк, д. вет. наук, професор, завідувач кафедри хірургії і патофізіології імені академіка І. О. Поваженка НУБіП України. 